\title{
Association of medullary sponge kidney and hyperparathyroidism with RET G691S/ S904S polymorphism: a case report
}

\author{
Muhammad Usman Janjua', Xiao-dan Long ${ }^{1}$, Zhao-hui Mo' ${ }^{1}$, Chang-sheng Dong ${ }^{2}$ and Ping Jin ${ }^{1 *}$
}

\begin{abstract}
Background: Medullary sponge kidney is a rare renal malformation, which usually manifests as nephrocalcinosis, renal tubular acidosis, and recurrent urinary tract infections. Medullary sponge kidney is often associated with renal developmental anomalies and tumors, and its exact pathogenesis is not yet clearly explained. Given the key role of the interaction of glial cell line-derived neurotrophic factor gene, GDNF, and the "rearranged during transfection" proto-oncogene, RET, in kidney and urinary tract development, variations in these genes are proposed to be candidates for medullary sponge kidney. Hyperparathyroidism is observed in a few patients with medullary sponge kidney, but the exact pathogenesis of this association is unknown. This case report highlights the coexistence of these two conditions associated with RET polymorphism, which contributes toward the understanding of the pathogenesis of medullary sponge kidney.
\end{abstract}

Case presentation: A 52-year-old Chinese woman with recurrent renal stones presented to our hospital. Subsequently she was diagnosed as having medullary sponge kidney and tertiary hyperparathyroidism and underwent parathyroidectomy. Genomic DNA was isolated from lymphocytes and the GDNF and RET genes were determined by Sanger sequencing. Two RET polymorphisms were found in our patient, one was nonsynonymous c.2071G>A (G691S; rs1799939) located in exon 11, the other was synonymous c.2712C>G. (p.S904S; rs1800863) located in exon 15.

Conclusions: We demonstrated a case of medullary sponge kidney combined with tertiary hyperparathyroidism, which contributes to further understanding of the pathogenesis of this disease. Besides, we also found RET G691S/S904S polymorphism in this patient, but additional studies are required to explore the role of the RET gene in medullary sponge kidney with hyperparathyroidism.

Keywords: Medullary sponge kidney, Hyperparathyroidism, RET, Polymorphism

\section{Background}

Medullary sponge kidney (MSK) is a nephropathy which usually manifests as nephrolithiasis, renal tubular acidosis, concentration defects, medullary cystic dilatations, and recurrent urinary tract infections. Its incidence is $1 / 20,000$ to $1 / 5000$ in the general population, 3 to $5 \%$ in patients with kidney stones, and up to $20 \%$ in patients with recurrent kidney stones [1]. MSK generally occurs sporadically, but an apparently

\footnotetext{
* Correspondence: jping7676@hotmail.com

'Department of Endocrinology, The Third Xiangya Hospital, Central South University, Tongzipo Road, Changsha 410007, Hunan Province, People's Republic of China

Full list of author information is available at the end of the article
}

autosomal dominant inheritance has also been observed in familial cases [2]. MSK is often associated with renal developmental anomalies and tumors, such as Wilms tumor, horseshoe kidney, and contralateral congenital small kidney, which supports the conviction that it is a developmental disorder [3]. Nephrogenesis depends on reciprocal inductive interactions between the ureteric bud and the metanephric blastema. During renal organogenesis, glial cell line-derived neurotrophic factor (GDNF) produced by the metanephric blastema, and its receptor "rearranged during transfection" (RET) on the ureteric bud, induces ureteric bud outgrowth and branching from Wolff's duct $[4,5]$. Thus, some speculated that variants of GDNF and RET genes, which play a key role in

(c) The Author(s). 2018 Open Access This article is distributed under the terms of the Creative Commons Attribution 4.0 International License (http://creativecommons.org/licenses/by/4.0/), which permits unrestricted use, distribution, and 
kidney and urinary tract development, maybe reasonable candidates for MSK. Hyperparathyroidism is observed in a few patients with MSK, but the exact pathogenesis of this association is unknown $[3,6]$. In the current study, we present a case of MSK accompanied with tertiary hyperparathyroidism in whom we analyzed the GDNF and RET gene variations, which contributes to further understanding of the pathogenesis of this disease.

\section{Case presentation}

A 52-year-old Chinese woman presented to our hospital in September 2012 with a complaint of recurrent renal stones for 6 years. The renal stones were first discovered at a local hospital 6 years ago and then she underwent bilateral ureteroscopic lithotomy and ultrasonic lithotripsy several times, but the calculus still relapsed and her serum creatinine gradually increased to 240 to 300 umol/L. She was a teacher living with her husband and two children, all healthy, in a small city. She did not smoke tobacco or consume alcohol. She had no significant past medical history, she had not suffered from any infectious disease, and she did not suffer from any chronic illness. There was no family history of similar disease or any other chronic illness. There was no history of allergy to any food or drugs. On physical examination: temperature $(\mathrm{T}) 37.5{ }^{\circ} \mathrm{C}$, pulse $(\mathrm{P}) 82 /$ minute, respiratory rate $(\mathrm{R})$ 20/minute, blood pressure (BP) 130/ $80 \mathrm{mmHg}$, weight (W) $51 \mathrm{~kg}$, and height $(\mathrm{H}) 154 \mathrm{~cm}$. Respiratory movement and cardiac examination were normal. On abdominal examination no masses or tenderness were noted on both light and deep palpation. Her liver and spleen were not palpable. A sensory and motor system examination did not reveal any abnormality. Her neurological reflexes were normal. A routine urine examination showed: white blood cell $87 / \mathrm{hpf}(\mathrm{WBC} 2+$ ), red blood cell $34 / \mathrm{hpf}(\mathrm{RBC} 2+)$, and $\mathrm{pH}$ 7. 0. A routine blood test showed: hemoglobin $(\mathrm{Hb}) 95 \mathrm{~g} / \mathrm{L}$. Her serum potassium was $3.2 \mathrm{mmol} / \mathrm{L}$, calcium $2.92 \mathrm{mmol} / \mathrm{L}$, phosphate $1.3 \mathrm{mmol} / \mathrm{L}$, carbon dioxide combining power $\left(\mathrm{CO}_{2} \mathrm{CP}\right)$ $17.8 \mathrm{mmol} / \mathrm{L}$, creatinine $249 \mu \mathrm{mol} / \mathrm{L}$, serum parathyroid hormone (PTH) $1147 \mathrm{pg} / \mathrm{ml}$ (Table 1), 25-hydroxyvitamin D3 level $42.98 \mathrm{nmol} / \mathrm{L}$ with reference range (RR) of $47.7-$ $144 \mathrm{nmol} / \mathrm{L}, 24$-hour urinary calcium $8.98 \mathrm{mmol} /$ day (RR, 2.5-7.5 mmol/day), and 24-hour urine potassium $26.8 \mathrm{mmol} /$ day. Liver and thyroid functions were all normal. Urine culture showed the presence of Escherichia coli. Renal ultrasound showed multiple stones, cysts, and calcified lesions. Computed tomography (CT) of her kidney showed MSK and polycystic kidney disease (Fig. 1a). Ultrasonography of her thyroid and parathyroid showed two hypoechoic nodules in the right lobe of her thyroid with the larger one of $26 \times 18 \mathrm{~mm}$. She was diagnosed as having MSK complicated with tertiary hyperparathyroidism and underwent right parathyroidectomy on September 18, 2012. Histopathologic examination revealed adenomatous hyperplasia of parathyroid glands (Fig. 1b). After surgery, her serum potassium was $3.3 \mathrm{mmol} / \mathrm{L}$, calcium $2.81 \mathrm{mmol} /$ $\mathrm{L}$, phosphate $1.01 \mathrm{mmol} / \mathrm{L}, \mathrm{CO}_{2} \mathrm{CP} 16.1 \mathrm{mmol} / \mathrm{L}, \mathrm{PTH}$ $742.5 \mathrm{pg} / \mathrm{ml}$, and serum creatinine $231 \mu \mathrm{mol} / \mathrm{L}$ (Table 1). The oral form of iron and calcitriol was administered.

In March 2013, 6 months after resection of her right parathyroid glands she was re-hospitalized because of generalized bone pain of 1 month's duration. A routine urine examination showed: white blood cell 45/hpf (WBC1+), red blood cell $27 / \mathrm{hpf}(\mathrm{RBC1} 1+)$, and $\mathrm{pH}$ 7. 5. A routine blood test showed: $\mathrm{Hb} 88 \mathrm{~g} / \mathrm{L}$. Her serum potassium was $3.1 \mathrm{mmol} / \mathrm{L}$, calcium $2.83 \mathrm{mmol} / \mathrm{L}$, phosphorus $1.21 \mathrm{mmol} / \mathrm{L}, \mathrm{CO}_{2} \mathrm{CP} 19.7 \mathrm{mmol} / \mathrm{L}$, creatinine $265 \mu \mathrm{mol} /$ L, and PTH $1378 \mathrm{pg} / \mathrm{ml}$ (Table 1). Her 24-hour urinary calcium was $8.5 \mathrm{mmol} / \mathrm{L}$ and 24-hour urinary potassium $29.6 \mathrm{mmol} / \mathrm{L}$. A bone scintigraphy for whole body with ${ }^{99 \mathrm{~m}}$ Tc revealed increased activity in skull, rib, and sternum (Fig. 1c). Parathyroid and thyroid ultrasound showed multiple hypoechoic masses in left lobe, with largest ones being $25 \times 23 \mathrm{~mm}$ and $22 \times 20 \mathrm{~mm}$. She was diagnosed as having MSK and tertiary hyperparathyroidism and underwent left lobe parathyroidectomy on March 27, 2013. A pathological examination of the resected parathyroid tissue showed parathyroid nodular hyperplasia (Fig. 1d). After surgery, her serum calcium was $2.25 \mathrm{mmol} / \mathrm{L}$,

Table 1 Biochemical characteristics of the patient

\begin{tabular}{|c|c|c|c|c|c|c|}
\hline & 6 Sep 2012 & 20 Sep 2012 & 4 Mar 2013 & 28 Mar 2013 & 7 Jul 2016 & Reference ranges \\
\hline Calcium (mmol/L) & 2.92 & 2.81 & 2.83 & 2.25 & 2.09 & $2.08-2.8$ \\
\hline Phosphate (mmol/L) & 1.3 & 1.01 & 1.21 & 1.07 & 2.37 & $0.9-1.34$ \\
\hline PTH (pg/mL) & 1147 & 742.5 & 1378 & 47.8 & 766.4 & $15-65$ \\
\hline Potassium (mmol/L) & 3.2 & 3.3 & 3.1 & 3.7 & 4.0 & $3.5-5.2$ \\
\hline $\mathrm{CO}_{2} \mathrm{CP}(\mathrm{mmol} / \mathrm{L})$ & 17.8 & 16.1 & 19.7 & 16.8 & 15.6 & $23-29$ \\
\hline CRE (umol/L) & 249 & 231 & 265 & 257 & 766 & $45-104$ \\
\hline Urine $\mathrm{PH}$ & 7.0 & & 7.5 & & 7.0 & \\
\hline
\end{tabular}



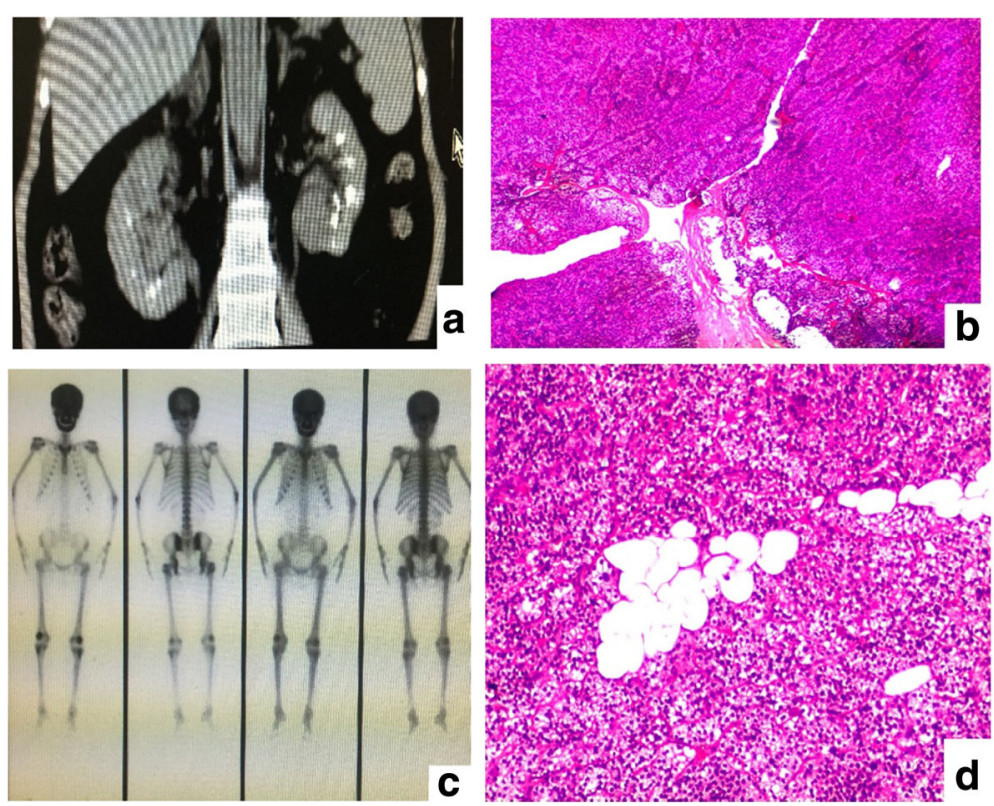

Fig. 1 a Computed tomography of the kidney showed a great amount of dotted and patchy compact shades at deep medullary sections of both kidneys, which indicated medullary sponge kidney and polycystic kidney disease. b Histological view of resected right parathyroid tissue showed adenomatous hyperplasia of parathyroid glands stain at magnification $\times 100$ ( $f$ ). c A ${ }^{99 m}$ Tc bone scan revealing increased uptake. $\mathbf{d}$ The histological examination of the resected left parathyroid tissue showed nodular hyperplasia and active regional cellular hyperplasia which was in accordance with parathyroid nodular hyperplasia

phosphorus $1.07 \mathrm{mmol} / \mathrm{L}$, potassium $3.7 \mathrm{mmol} / \mathrm{L}, \mathrm{CO}_{2} \mathrm{CP}$ $16.8 \mathrm{mmol} / \mathrm{L}, \mathrm{PTH} 47.81 \mathrm{pg} / \mathrm{ml}$, and creatinine $257 \mu \mathrm{mol} /$ L (Table 1). Subsequently she was prescribed with oral form of iron and calcitriol at the time of discharge; later, she did not return for the scheduled follow-up visits.

On July 7, 2016, 4 years after parathyroidectomy she was readmitted to our hospital with the complaint of dizziness. A physical examination showed pale appearance, visible thyroid surgery scar, and mild swelling of both lower extremities. A routine urine analysis showed: white blood cell 41/hpf $(\mathrm{WBC}+)$ and $\mathrm{pH}$ 7.0. A routine blood test showed: $\mathrm{Hb} 76 \mathrm{~g} / \mathrm{L}$, potassium $4.0 \mathrm{mmol} / \mathrm{L}$, calcium $2.09 \mathrm{mmol} / \mathrm{L}$, phosphorus $2.37 \mathrm{mmol} / \mathrm{L}, \mathrm{CO}_{2} \mathrm{CP} 15.6 \mathrm{mmol} / \mathrm{L}$, serum creatinine $766 \mu \mathrm{mol} / \mathrm{L}$, and PTH 766.4 pg/ml (Table 1). Renal ultrasound showed MSK, multiple stones in both kidneys, and polycystic kidney disease. She was diagnosed as having MSK and tertiary hyperparathyroidism and underwent renal replacement therapy (hemodialysis). She was started on replacement therapy. At 1-year follow-up, she was undergoing hemodialysis twice a week. A routine blood test showed: Hb 80 g/L. A routine urine analysis showed: $\mathrm{PH}$ 7.5 and protein positive (Pro2+). Her serum potassium level was $4.2 \mathrm{mmol} / \mathrm{L}$, calcium $2.22 \mathrm{mmol} / \mathrm{L}$, phosphorus $1.53 \mathrm{mmol} / \mathrm{L}, \mathrm{CO}_{2} \mathrm{CP} 26.1 \mathrm{mmol} / \mathrm{L}$, creatinine $619 \mu \mathrm{mol} / \mathrm{L}$, and PTH $546 \mathrm{pg} / \mathrm{ml}$.

Given the key role of the GDNF-RET interaction in kidney and urinary tract development, anomalies in these molecules are reasonable candidates for explaining a disorder such as MSK. However, mutations in RET proto-oncogene are also present in $97 \%$ of individuals with multiple endocrine neoplasia (MEN) 2A (MEN2A). In order to explore the possible genetic mechanisms, we analyzed the GDNF and RET genes in this patient. After obtaining informed consent from our patient, genomic DNA was extracted from peripheral blood leukocytes by standard phenol-chloroform procedures. All 20 exons and flanking splice sites of the GDNF and RET genes were amplified by polymerase chain reaction (PCR) with the primers listed in Table 2. Mutations were identified by direct sequencing of PCR products on an ABI 3730xl automated sequencer (Applied Biosystems, USA). Two RET polymorphisms were found in this patient, one was nonsynonymous c.2071G>A (G691S; rs1799939) located in exon 11 (Fig. 2a); the other was synonymous c. 2712 C >G (p.S904S; rs1800863) located in exon 15 (Fig. 2b). No mutation was found in the GDNF gene. Both parents of our patient are deceased. Further genetic testing of her husband, daughter, and sister were all negative for this polymorphism.

\section{Discussion}

In our study, we present a case of 52-year-old woman with recurrent renal stones, who was subsequently diagnosed as having MSK and tertiary hyperparathyroidism. 
Table 2 Polymerase chain reaction and sequencing primers of RET gene

\begin{tabular}{|c|c|c|c|}
\hline Exon & Sense primer & $\begin{array}{l}\text { PCR product } \\
\text { (base pairs) }\end{array}$ & $\mathrm{T}\left({ }^{\circ} \mathrm{C}\right)$ \\
\hline RET-1 & 5'- GCACCCGCCATCCAGACC -3' & 567 & 62 \\
\hline RET-1 & 5'- TCTCCTGCCGAAACAGAACTC -3' & & \\
\hline RET-2 & 5'- CGGCTTGGATGATTGAGAATAGG-3' & 583 & 58 \\
\hline RET-2 & 5'- GTGATAAGGGCGGCTTGAGG-3' & & \\
\hline RET-3 & 5'-TCCTCCCCATTCCCGACTG - 3' & 573 & 56 \\
\hline RET-3 & 5'- AGGCAGGCAAGATTCCAACC-3' & & \\
\hline RET-4 & 5'-CAACCAGCACGAGTGAGGAC - $3^{\prime}$ & 640 & 60 \\
\hline RET-4 & 5'-ACGGAGGCGAAGGACAAATG $-3^{\prime}$ & & \\
\hline RET-5 & 5'-AACACACATCTGGTCCACCTATG - $3^{\prime}$ & 375 & 56 \\
\hline RET-5 & 5'- AAGAGCGAGCACCTCATTTCC-3' & & \\
\hline RET-6 & 5'-GTGTGAAAGTGCGTGTTTGC - -3' & 428 & 60 \\
\hline RET-6 & 5'-CAGTCTACTCTGTGCTGGTTG -3' & & \\
\hline RET-7 & 5'- GGACTTAGGCTGTGTGGGAATC-3' & 516 & 58 \\
\hline RET-7 & 5'- -CTGGAAGGAGCAACCATTTACTG-3' & & \\
\hline RET-8 & 5'-GCTGGTGCTGTTCCCTGTC - -3' & 375 & \\
\hline RET-8 & 5'-CACTGCTGCCCGCTATGC - -3' & & \\
\hline RET-9 & 5'-CCTCCAGTTGCTCCTCCCTAG -3' & 470 & \\
\hline RET-9 & 5'- CTGCTTCTGAAATCTGTGTGTGC-3' & & \\
\hline RET-10 & 5'-GGCAGAGTCCTTTGTTCAGATG -3' & 452 & 58 \\
\hline RET-10 & 5'- CAGCAATTTCCTCCCTTGTTGG-3' & & \\
\hline RET-11 & 5'-GAGCCTCTGTCTCCATCTGTAAG -3' & 606 & 56 \\
\hline RET-11 & 5'-CTCGTCTGCCCAGCGTTG -3 & & \\
\hline RET-12 & 5' GCAGAGACAGGCAGCGTTG-3' & 499 & 58 \\
\hline RET-12 & 5'- CCTTCCAGGGAGAGCAAAGTC-3' & & \\
\hline RET-13 & 5'- AGAAGCCTCAAGCAGCATCG-3' & 432 & 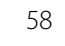 \\
\hline RET-13 & 5'-TCAGCCCGTGGACTCAGC-3' & & \\
\hline RET-14 & 5'- GGCAGAGAGCAAGTGGTTCAAG-3' & 618 & 60 \\
\hline RET-14 & 5'- GGGCGTGGTGGAGTCAGG-3' & & \\
\hline RET-15 & 5'- CCACACACCACCCCTCTG-3' & 401 & 58 \\
\hline RET-15 & 5'-GGCTGAGCGGAGTTCTAATTG -3' & & \\
\hline RET-16 & 5'-CACTCCTCTGGTTACTGAAAGC - -3' & 370 & 56 \\
\hline RET-16 & 5'- CATTTGCCTCACGAACACATC-3' & & \\
\hline RET-17 & 5'- CCAGACCCAGGCTGACATC-3' & 449 & 00 \\
\hline RET-17 & 5'- ATCTACTGCCACACCCAAGG-3' & & \\
\hline RET-18 & 5'- AGGGTGCGATGGCTGTGG-3' & 352 & 50 \\
\hline RET-18 & 5'- AGGGTTCAATCTGCTGTCTGC-3' & & \\
\hline RET-19 & 5'-CTTGGAGAGGTCAGGAGATTGG -3' & 453 & 58 \\
\hline RET-19 & 5'-AATGCCTAAATGTAAACTGGATGC - $3^{\prime}$ & & \\
\hline RET-20 & 5'- TTGGAAACCTGGAACACAAAACC-3' & 430 & 62 \\
\hline RET-20 & 5'- GCCACCTGGGAACTGAACAC-3' & & \\
\hline
\end{tabular}

$P C R$ polymerase chain reaction, $R E T$ rearranged during transfection, $T$ annealing temperature for the $P C R$ reactions
Although hyperparathyroidism is reported in a few patients with MSK, the exact association is still controversial. Our study indicates that MSK might be the primary factor, and parathyroid adenoma might occur secondary to long-term negative calcium balance caused by MSK, which highlights the importance of early detection, treatment, and further prevention of complications of MSK. Given the key role of the GDNF and RET interaction in kidney and urinary tract development, we also analyzed and found RET G691S/S904S polymorphism in this patient, but additional studies are required to explore the exact mechanism of the RET gene in MSK with hyperparathyroidism.

MSK is a kidney malformation and is often combined with impaired renal tubular functions, such as concentration defects, and partial or complete distal renal tubular acidosis (dRTA). Fabris et al. [4] showed that over $80 \%$ of patients with MSK had complete or incomplete dRTA. Chemical analyses of the stone in patients with MSK showed that $67 \%$ of them were mainly calcium phosphate and 33\% were calcium oxalate which further confirmed the prevalence of distal tubular acidosis in patients with MSK [7]. Some proposed that dRTA played a key role in the pathogenesis of MSK, which could lead to hypercalciuria, hypocitraturia, and stone formation. In our case, our patient had recurrent renal stones, urinary tract infection, hypokalemia, morning urine $\mathrm{pH}>5.5$, and acidosis, which were consistent with MSK and dRTA. Hyperparathyroidism is also reportedly associated with a few patients with MSK $[3,6]$, but the exact association between the two diseases is still controversial as both diseases can manifest as kidney stones and excessive urinary calcium excretion. Some scholars believe that hyperparathyroidism is a cause of MSK and triggers nephrolithiasis in these patients [6], while others believe that MSK could be the primary factor, and parathyroid adenoma might occur secondary to long-term negative calcium balance caused by high urinary calcium [4]. In our case, nephrocalcinosis preceded the onset of hyperparathyroidism, while the level of PTH continued to rise after parathyroidectomy. Thus, we hypothesized the tertiary hyperparathyroidism in this patient, as proved by parathyroid pathology, is secondary to MSK, due to long-term distal tubular acidosis and negative calcium balance caused by high urinary calcium.

As MSK is considered a congenital disease, it is speculated that the GDNF and RET genes, which play a key role in the kidney-urinary tract development and nephrogenesis, might be the reasonable candidates for MSK. Torregrossa et al. [8] analyzed GDNF and RET genes of 55 patients with sporadic MSK and found eight patients with MSK had heterozygous variations of GDNF gene c. $-45 \mathrm{G}>\mathrm{C}$, c. $-27+18 \mathrm{G}>\mathrm{A}$. RET encodes a receptor tyrosine kinase, expressed primarily in neural crest and 


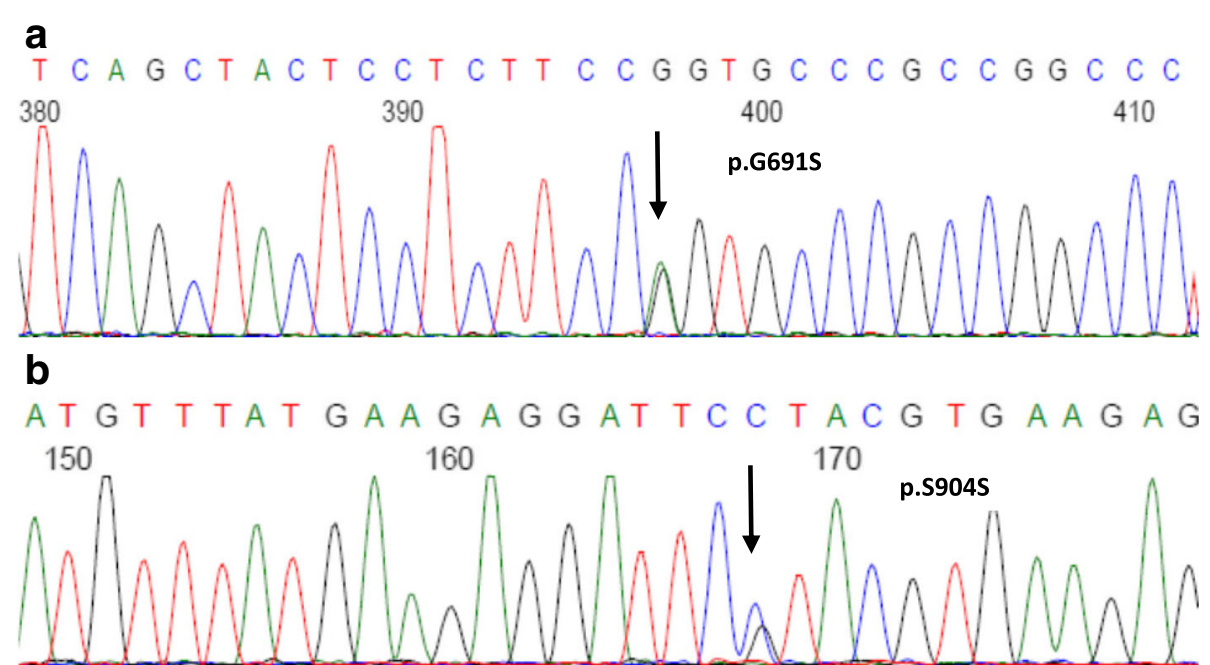

Fig. 2 The RET gene polymorphism found in the patient with medullary sponge kidney (indicated by an arrow). a c.2071G>A(G691S) b c. 2712 C > G. (p.S904S)

urogenital precursor cells. It is a developmentally important gene, required for kidney morphogenesis, maturation of peripheral nervous system lineages, and for differentiation of spermatogonia. In RET knockout mice, the loss of the RET protein results in anomalies of renal embryogenesis, which indicates that the RET protein is required for the development of the urinary excretory system. Primary hyperparathyroidism (PHPT) may occur as part of a complex syndrome or as an isolated disorder. Syndromic PHPT includes MEN types 1 to 4 (MEN1 to MEN4). RET gene mutations were also found in $97 \%$ of patients with MEN2A, who have an increased risk for parathyroid adenoma or hyperplasia, medullary carcinoma of the thyroid, and pheochromocytoma [9]. Intriguingly, Diouf et al. [10] reported the case of a woman with MSK combined with MEN2A, that is, hyperparathyroidism and medullary thyroid carcinoma (MTC), due to RET C634Y mutation. In addition, sporadic forms of parathyroid tumors may arise because of somatic gene abnormalities. To date, reports have shown that more than $10 \%$ of patients with hyperparathyroidism may have a germline mutation involving the $M E N 1$, $R E T$, cell division cycle 73 (CDC73), calcium-sensing receptor (CASR), cyclin-dependent kinase inhibitor (CDNK1B), or PTH genes. Thakker [11] suggested that the patients with hyperparathyroidism in whom there is a high suspicion of a genetic etiology (for example, young age at onset, multigland disease, parathyroid carcinoma, or atypical parathyroid adenoma) should be offered genetic counseling and germline mutation testing. In our patient, the RET gene polymorphisms G691S (exon 11) and S904S (exon 15) were identified, but no GDNF variants were found. It was shown that the nonsynonymous RET G691S polymorphism is able to increase downstream signaling compared with $R E T$ wild type $[12,13]$. Moreover, some studies have demonstrated that the oncogenic activity of RET pathogenic genes in MTC is enhanced by the presence of G691S, suggesting a possible modifier role of this nonsynonymous RET polymorphism [14, 15]. Previous studies [16] have shown that the polymorphisms G691S and S904S of RET are in linkage disequilibrium with each other. Robledo et al. [17] analyzed the polymorphisms G691S and S904S of RET in 104 patients with MEN2A, and found the homozygous for these polymorphisms were, on average, 10 years younger at the time of diagnosis compared with heterozygous and wild-type homozygous, indicating that the G691S/S904S variants of RET have a modifier effect on the age at onset of MEN2A. However, the exact mechanism of RET G691S/S904S polymorphism in the pathogenesis of MSK and hyperparathyroidism still remains to be uncovered.

Considering the pivotal role of incomplete dRTA in MSK, Fabris et al. [18] recommended orally administered alkali citrate in patients with MSK with at least one urine abnormality, and found quite positive effects: the stone rate decreased from 0.58 to 0.10 per year, a $50 \%$ decrease in their calciuria, and a $75 \%$ rise in their citrate levels, with an improvement in their bone mineral density. Other therapeutic measures include drinking plenty of water, reducing dietary sodium and proteins, and increasing vegetable and fruit intake. For patients with very frequently recurring stones, the minimally invasive percutaneous nephrolithotomy can be an option [19]. The progression of MSK is slow and prognosis is usually good. End-stage renal disease in our patient can probably be attributed to persistent kidney damage as a result of long-term uncorrected dRTA, 
years of undiagnosed hyperparathyroidism, recurrent kidney stones requiring multiple admissions, and repeated episodes of urinary tract infections, all of which complicated the course of this apparently benign disease and resulted in total loss of kidney function. Early detection, treatment, and further prevention of complications will slow the kidney damage and prevent the need of renal replacement therapy in patients with MSK.

\section{Conclusions}

We demonstrated a case of MSK combined with tertiary hyperparathyroidism, which further expands the pathophysiology of this disease. Early recognition of MSK symptoms has important clinical implications for the prevention of further progress of the disease. Besides, we also found RET G691S/S904S polymorphism in this patient, but additional studies are required to explore the exact mechanism of the RET gene in MSK with hyperparathyroidism.

\section{Abbreviations \\ BP: Blood pressure; CASR : Calcium-sensing receptor; CDC73 : Cell division cycle 73; CDNK1B : Cyclin-dependent kinase inhibitor; $\mathrm{CO}_{2} \mathrm{CP}$ : Carbon dioxide combining power; CT: Computed tomography; dRTA: Distal renal tubular acidosis; GDNF: Glial cell line-derived neurotrophic factor; H: Height; Hb: Hemoglobin; MEN: Multiple endocrine neoplasia; MSK: Medullary sponge kidney; MTC: Medullary thyroid carcinoma; P: Pulse; PCR: Polymerase chain reaction; PHPT: Primary hyperparathyroidism; PTH: Parathyroid hormone; R: Respiratory rate; RET: Rearranged during transfection; RR : Reference range; T: Temperature; W: Weight}

\section{Acknowledgements}

We wish to thank the patient and her relatives for consenting to the publication of this case report.

\section{Funding}

This study was supported by the National Natural Science Foundation of China (81670730, 81100583), Natural Science Foundation of Hunan Province (2016JJ4103).

\section{Availability of data and materials}

All laboratory data relevant to this case report can be found in the "Case presentation" section of this report.

\section{Authors' contributions}

$\mathrm{MUJ}$ is the first author and wrote this manuscript; MUJ and XDL performed the research. CSD and ZHM coordinated the research; PJ designed the research study. All authors read and approved the final manuscript.

\section{Ethics approval and consent to participate}

All procedures followed were in accordance with the ethical standards of the responsible committee on human experimentation (institutional and national) and with Helsinki Declaration of 1975, as revised in 2000.

\section{Consent for publication}

Written informed consent was obtained from the patient for publication of this case report and any accompanying images. A copy of the written consent is available for review by the Editor-in-Chief of this journal.

\section{Competing interests}

The authors declare that they have no competing interests.

\section{Publisher's Note}

Springer Nature remains neutral with regard to jurisdictional claims in published maps and institutional affiliations.

\section{Author details}

'Department of Endocrinology, The Third Xiangya Hospital, Central South University, Tongzipo Road, Changsha 410007, Hunan Province, People's Republic of China. ${ }^{2}$ Department of Anesthesia, The Affiliated Tumor Hospital of Xiangya Medical School of Central South University, Changsha 410007, Hunan, China.

Received: 27 January 2018 Accepted: 5 June 2018

Published online: 09 July 2018

\section{References}

1. Gambaro G, Feltrin GP, Lupo A, Bonfante L, D'Angelo A, Antonello A. Medullary sponge kidney (Lenarduzzi-Cacchi-Ricci disease): a Padua medical school discovery in the 1930s. Kidney Int. 2006;69(4):663-70.

2. Fabris A, Lupo A, Ferraro PM, Anglani F, Pei Y, Danza FM, Gambaro G. Familial clustering of medullary sponge kidney is autosomal dominant with reduced penetrance and variable expressivity. Kidney Int. 2013;83(2):272-7.

3. Gambaro G, Fabris A, Citron L, Tosetto E, Anglani F, Bellan F, Conte M, Bonfante L, Lupo A, D'Angelo A. An unusual association of contralateral congenital small kidney, reduced renal function and hyperparathyroidism in sponge kidney patients: on the track of the molecular basis. Nephrol Dial Transplant. 2005:20(6):1042-7.

4. Fabris A, Anglani F, Lupo A, Gambaro G. Medullary sponge kidney: state of the art. Nephrol Dial Transplant. 2013;28(5):1111-9.

5. Ria P, Fabris A, Dalla Gassa A, Zaza G, Lupo A, Gambaro G. New non-renal congenital disorders associated with medullary sponge kidney (MSK) support the pathogenic role of GDNF and point to the diagnosis of MSK in recurrent stone formers. Urolithiasis. 2017:45(4):359-62.

6. Maschio G, Tessitore N, D'Angelo A, Fabris A, Corgnati A, Oldrizzi L, Loschiavo C, Lupo A, Valvo E, Gammaro L, Rugiu C. Medullary sponge kidney and hyperparathyroidism-a puzzling association. Am J Nephrol. 1982;2(2):77-84.

7. A F, Bernich P, Abaterusso C, Marchionna N, Canciani C, Nouvenne A, Zamboni M, Lupo A, Gambaro G. Bone disease in medullary sponge kidney and effect of potassium citrate treatment. Clin J Am Soc Nephrol. 2009;4:1974-9.

8. Torregrossa R, Anglani F, Fabris A, Gozzini A, Tanini A, Del Prete D, Cristofaro R, Artifoni L, Abaterusso C, Marchionna N, Lupo A, D'Angelo A, Gambaro G. Identification of GDNF gene sequence variations in patients with medullary sponge kidney disease. Clin J Am Soc Nephrol. 2010;5:1205-10.

9. Mulligan LM, Eng C, Healey CS, Clayton D, Kwok JB, Gardner E, Ponder MA, Frilling A, Jackson CE, Lehnert $\mathrm{H}$, et al. Specific mutations of the RET protooncogene are related to disease phenotype in MEN 2A and FMTC. Nat Genet. 1994;6(1):70-4

10. Diouf B, Ka EH, Calender A, Giraud S, Diop TM. Association of medullary sponge kidney disease and multiple endocrine neoplasia type IIA due to RET gene mutation: is there a causal relationship? Nephrol Dial Transplant. 2000;15(12):2062-3.

11. Thakker RV. Genetics of parathyroid tumours. J Intern Med. 2016 Dec;280(6): 574-83.

12. Sawai H, Okada Y, Kazanjian K, Kim J, Hasan S, Hines OJ, Reber HA, Hoon DS, Eibl G. The G691S RET polymorphism increases glial cell line-derived neurotrophic factor-induced pancreatic cancer cell invasion by amplifying mitogen-activated protein kinase signaling. Cancer Res. 2005;65(24):11536-44.

13. N N, Tanemura A, Murali R, Scolyer RA, Huang S, Arigami T, Yanagita S, Chong KK, Thompson JF, Morton DL, Hoon DS. Functional RET G691S polymorphism in cutaneous malignant melanoma. Oncogene. 2009; 28(34):3058-68.

14. Borrello MG, Aiello A, Peissel B, Rizzetti MG, Mondellini P, Degl'Innocenti D, Catalano V, Gobbo M, Collini P, Bongarzone I, Pierotti MA, Greco A, Seregni E. Functional characterization of the MTC-associated germline RET-K666E mutation: evidence of oncogenic potential enhanced by the G691S polymorphism. Endocr Relat Cancer. 2011;18(4):519-27.

15. Colombo C, Minna E, Rizzetti MG, Romeo P, Lecis D, Persani L, Mondellini $P$, Pierotti MA, Greco A, Fugazzola L, Borrello MG. The modifier role of RETG691S polymorphism in hereditary medullary thyroid carcinoma: functional characterization and expression/penetrance studies. Orphanet J Rare Dis. 2015;10(1):25

16. Gil L, Azañedo M, Pollán M, Cristobal E, Arribas B, García-Albert L, García-Sáiz A, Maestro ML, Torres A, Menárguez J, Rojas JM. Genetic analysis of RET, GFR 
alpha 1 and GDNF genes in Spanish families with multiple endocrine neoplasia type 2A. Int J Cancer. 2002;99(2):299-304.

17. Robledo M, Gil L, Pollán M, Cebrián A, Ruíz S, Azañedo M, Benitez J, Menárguez J, Rojas JM. Polymorphisms G691S/S904S of RET as genetic modifiers of MEN 2A. Cancer Res. 2003;63(8):1814-7.

18. Fabris A, Lupo A, Bernich P, Abaterusso C, Marchionna N, Nouvenne A, Gambaro G. Long-term treatment with potassium citrate and renal stones in medullary sponge kidney. Clin J Am Soc Nephrol. 2010;5(9):1663-8.

19. Sun H, Zhang Z, Yuan J, Liu Y, Lei M, Luo J, Wan SP, Zeng G. Safety and efficacy of minimally invasive percutaneous nephrolithotomy in the treatment of patients with medullary sponge kidney. Urolithiasis. 2016; 44(5):421-6.

Ready to submit your research? Choose BMC and benefit from:

- fast, convenient online submission

- thorough peer review by experienced researchers in your field

- rapid publication on acceptance

- support for research data, including large and complex data types

- gold Open Access which fosters wider collaboration and increased citations

- maximum visibility for your research: over $100 \mathrm{M}$ website views per year 